\title{
Participatory varietal selection: an approach used for the selection of lowland NERICA varieties in Niger
}

\author{
Amir SIDO YACOUBA ${ }^{1}$, Ousmane ZAKARI MOUSSA ${ }^{2 *}$, Aboubacar KADRI ${ }^{2}$, \\ Saley KAKA ${ }^{1}$ and Germaine IBROH ${ }^{1}$ \\ ${ }^{I}$ National Institute of Agronomical Research of Niger (INRAN). \\ ${ }^{2}$ University Abdou Moumouni of Niamey, Faculty of Agronomy, BP: 10960 Niamey, Niger. \\ *Corresponding author; E-mail: zakari@refer.ne
}

\begin{abstract}
A process of diffusion of new rice varieties called participatory varietal selection (PVS) through participatory varietal testing was adopted in this study. The objective of this study was to introduce a participatory approach in using new rice varieties including NERICA to improve the productivity of rice in Niger. Six intra and inter specific varieties of rice and a local control (IR1529) were evaluated on the agronomic, socio-economic and technological traits. The tested varieties were WAS 4-B-B-9-1-4-TGR 48, NERICA-L-16, WAS 114-B-IDSA-B-WAS-1-1-TGR 144, WAS 173-B-B-13 - 7-TGR21, NERICA-L-39, NERICA-L-49. The tests were conducted on irrigated perimeters of Karma, Diambala and Sébéry during the dry and rainy seasons of 2006. The results of individual assessments highlighted two NERICA varieties: NERICA-L-49 and NERICA-L-39 and one intra-specific, WAS 4-BB-9-1-4-TGR 48. These varieties were selected for their high production potential (6 to $7 \mathrm{~T} / \mathrm{ha}$ in rural areas) and quality (good taste, good ability for processing, etc.). These varieties were approved in 2007. These new varieties were registered in national catalogue of plant species and varieties in 2012. Currently these varieties are disseminated on all irrigation schemes of Niger. This new strategy of introduction and diffusion of new technologies involving all the stakeholders in the sector in the process of evaluating new technologies helped accelerating the adoption of new rice technologies in Niger.
\end{abstract}

(C) 2013 International Formulae Group. All rights reserved.

Keyswords: Rice, NERICA, yield, PVS, Niger.

\section{INTRODUCTION}

Rice is an important food crop in SubSaharan Africa. However, the production of the most commonly grown local rice species is inadequate. They are broadly grouped into: Oryza sativa of Asian origin and the African rice (Oryza glaberrima). Several factors have affected their yields (ADRAO, 1996).

To overcome this situation, AfricaRice (WARDA) developed a new type of rice
NERICA (New Rice for Africa), with high yields and resistance to local constraints mainly designed for African small scale rice production conditions. The new plant type combines the advantage of having a rapid growth rate that suppress the adventitious plants, resistance and/or a tolerance to local stress inherited from the African parent plant, a high grain production and a resistance to lodging inherited from the Asiatic parent 
plant. NERICA is very popular with farmers not only because of it growth characteristics but also because of its grain quality (good taste) (ADRAO, 2005).

The new rice for Africa grows very well with low input where farmers cannot afford fertilizers or pesticides.

With the first success of NERICA upland, AfricaRice (WARDA) has targeted the rain fed low land and the irrigated systems with the inter specific crossings adapted to these ecosystems. For irrigated agroecosystem the first NERICA targeted were fixed 10 years ago.

In 2004, the evaluation of 70 intra and inter specific varieties of rice was done in many member countries of Africa Rice (WARDA) (Mali, Burkina Faso, and Niger). In Niger, the tests were conducted on two sites Sébéry and Bonféba. After two years of experiments (2004-2005), six intra and inter specific varieties were selected by the INRAN crop breeding program. These six varieties selected have proved to be the most productive and their yields were higher than those of the local control variety (check) which is IR1529-680-3 about 50\% in yield. Furthermore, they are early maturing and their tolerance to rice yellow mottle virus (score lof SES IRRI scale marking) which makes them preferred for rice production in Niger ( Niger ROCACARIZ report,2005).

Also, during a field visit at Bonféba site at maturity stage, these varieties were the most preferred by the farmers. The agronomic characteristics that lead to their choice are mainly: tillering ability (35.5\%), early maturity $(10.1 \%)$, grains thickness $(15.8 \%)$, panicle height $(14.1 \%)$, plant height $(5.4 \%)$, disease resistance (19.4\%), and leaf set up (2\%) (Niger ROCARIZ report, 2005).

From all the above characteristics presented by these new varieties of rice produced in Niger, and with the aim of giving farmers a wide range of high yielding varieties and responding to the need of all stakeholders, INRAN and PAFRIZ (CIRAD, 2000) have tested, in a participatory approach, the six best intra and inter specific varieties in farmer environmental conditions, during the dry and rainy seasons 2006. Three sites were used for the tests: Karma, Sébéry and Diambala (Sido et al., 2006).

The overall objective of this study was to introduce to farmers new rice varieties such as NERICA through a participatory approach in order to improve rice production in Niger.

The specific objectives were to:

- Evaluate the agronomic performance of NERICA;

- Identify farmers' choice among NERICA varieties (under field condition) and to know the criteria determining their choice;

- Select NERICA varieties that have high milling quality and good taste.

These varieties were approved in 2007. These new varieties were registered in national catalogue of plant species and varieties in 2012 (CNEV, 2012). Currently, these varieties are disseminated on all irrigation schemes of Niger.

\section{MATERIALS AND METHODS}

\section{Sites selection}

Three sites were selected: Karma, Sébéry and Diambala in Western Niger. The trials were conducted on farmers' fields. Two volunteer farmers were selected per site.

Rice varieties used for the experiment were three (3) NERICA, three (3) intrapecific and one local variety as follows:

1. WAS 4-B-B-9-1-4-TGR 48

2. WAS 122-IDSA-1-WAS-2-B-1-TGR 132 ( NERICA-L-16)

3. WAS 114-B-IDSA-B-WAS-1-1-TGR 144

4. WAS 173-B-B-13-7-TGR21

5. WAS161-B-6-WAS-B-TGR16 (NERICAL-39)

6. WAS 122-IDSA-1-B-IER-18-6 (NERICAL-49)

7. IR1529-680-3 (local check or control) called IR 1529

The pedigree and origin of the varieties are shown in Table 1.

\section{Evaluation methods}

The methods used in this study consisted of a scientific approach and farmers' evaluation. 
Table 1: Pedigree and origin of the varieties.

\begin{tabular}{lcc}
\hline Variety & Pedigree & Origin \\
\hline WAS 4-B-B-9-1-4-TGR 48 & IR13240-108-2-2-3/YAYA & WARDA \\
NERICA-L-16 & TOG5681/3*IR64 & WARDA \\
WAS 114-B-IDSA-B-WAS-1-1-TGR 144 & ITA305 / IR1320-108-2-2-3 & WARDA \\
WAS 173-B-B-13-7-TGR21 & BW293-2/4456 & WARDA \\
NERICA-L-39 & TOG5681 / 4*IR64 & WARDA \\
NERICA-L-49 & TOG5681/3*IR64 & WARDA \\
IR1529 ( local check) & SAGADIS (NI) x IR24 & IRRI \\
\hline
\end{tabular}

\section{Scientific Approach/ Agronomic evaluation}

- Experimental design: trials were laid out in a completely randomized block design with 3 replicates. Six varieties were compared to the local variety (IR 1529) in plots of $15 \mathrm{~m}^{2}$.

- Land preparation: the field was plowed using animal traction and was leveled manually.

- Transplanting: two seedlings per stand at a spacing of $20 \times 20 \mathrm{~cm}$ were used.

- Fertilizer application: this consisted of $200 \mathrm{~kg}$ per ha of NPK 15-15-15 at transplanting and $400 \mathrm{~kg}$ per ha urea in two split-applications $(200 \mathrm{~kg}$ per ha at plant establishment stage and $200 \mathrm{~kg}$ per ha at panicle stage).

- Weeding: weeding was done manually thrice.

\section{Farmers' field evaluation}

This was carried out in field at maturity stage.

\section{Observation and sampling methods}

Field scientific/ agronomic evaluation

The following data were recorded:

Dates of planting and of various field operations through the developmental stages from nursery to harvest, data on pests and diseases (were recorded using the IRRI SES scale), plant height (SES), number of panicles per $\mathrm{m}^{2}$, date at $50 \%$ panicle development, phenotypic acceptability, yield in tons per ha, percentage sterility and 1000 grains weight.

Farmers'field evaluation

A field visit was organized in Sébéry at maturity stage where questionnaires prepared for socio-economic studies were given to 40 farmers. Observations consisted of the criteria determining the choice, classification of varieties, etc.

\section{Post-harvest evaluation}

Parboiling: two subsamples of about $50 \mathrm{~kg}$ Paddy each were taken from each variety. One subsample was parboiled using the local parboiling procedure commonly used in Tillabery region in order to compare the quality of each cultivar depending on milling method. Paddy grains were soaked and parboiled and then sun-dried.

Pre-conditioning: before husking, the grain initial moisture was determined (AFNORV07 method), then pre conditioned at moisture content of $13-15 \%$ using sealed tanks. This was done in order to precondition the samples at the recommended moisture content for rice milling.

Milling: the milling quality of the conditioned grains was evaluated by the research team of the Food Technology Laboratory (LTA/ INRAN) at the SSL Rice Milling Small Scale Factory. The parameters assessed consisted of milling yield (for brown/ cargo rice and white rice), percentage broken rice, percentage husk and bran. A milling quality demonstration test was conducted at the $S S L$ rice milling factory in the presence of all people involved in the promotion of rice sector in Niger, in order to enable them to appreciate the milling procedure used and also the milling quality of each variety.

Rice tasting (done at the SSL Rice Milling Mini factory degustation test): this test was carried out at the PAFRIZ office. Milled rice grains (parboiled and non parboiled) were cooked and tasted by a panel 23 people divided in four groups. The parameters assessed were color, stickiness, taste and the general acceptance. A record card was used to evaluate the parameters and to classify them 
based on preference. For data processing reasons, the classification was converted into numerical values.

\section{Data analysis}

Data obtained from scientific evaluation were statistically analyzed by analysis of variance (ANOVA) using SAS software. Where significant differences were found, means were separated using Duncan Multiple Range Test (DMRT) 50\% level. Data from the socio economic evaluation were analyzed using SPSS program and the tendencies for choices of the varieties and the criteria determining these choices were clearly determined.

\section{RESULTS AND DISCUSSION Agronomic evaluation}

Yield is the most important parameter on agronomic basis (Hamadou et Sido, 1998). The results of the two (2) seasons study are shown in Table 2.

The data was pooled from the 3 sites. The percentage yield and rice production increment which could be derived from NERICA cultivation in Niger are shown. The results showed that there is a significant difference in yield between the varieties. NERICA-L-49 had the highest yield with 7.13 tons/ ha, $16 \%$ yield increase which was about 1 ton increase in rice production per ha compared to the local control (IR1529). IR 1529 showed good performance (6.14 ton/ha) in a rice based production system in Niger. An increase in yield of 2 tons compared to the national average yield on irrigation schemes which was 4 ton/ha (ONAHA, 1999) was achieved due to the fact that good cultural practices were ensured and the rice cultivation calendar was respected. Also, results from scientific work at AfricaRice (WARDA) (on NERICA showed that the presence of glaberrima genes was responsible for their good performance during the rainy season. The glaberrima cultivars were only cultivated during rainy season because they are not photo sensitive.

It was also given the yield by sites in order to evaluate the NERICA according to the localities where they are cultivated (Table 3).

The results obtained showed a weak variation in yield of varieties. The difference in yield of inter sites was not very significant. The genotypes kept their agronomic performances whatever the environment they were cultivated. For example, the NERICA-L49 recorded in Diambala (7.1 ton/ha), in Karma (7.17 ton/ha) and in Sébéry (7.07 ton/ha). That is in harmony with the reported literature which underlines the plasticity of interspecific and their broad adaptability and is said to have the ability to adapt to somewhat diversified environments.

For better quantification of the variable yield, other agronomic characteristics were analyzed. These included: the duration of growing cycle, number of panicle $/ \mathrm{m}^{2}$, percentage of sterility, weight of 1000 grains and phenotypic acceptability. The assessment of these various parameters was made according to the SES (Rice Standard Evaluation System) of IRRI (Table 4).

Duncan Multiple Range Test (DMRT) at $5 \%$ revealed a significant difference between the varieties tested for the height, the growing cycle, the percentage sterility and the weight of 1000 grains. It did not show any significant difference in the number of panicle per $\mathrm{m}^{2}$. The results of Table 4 show the precocity of NERICA compared to IR 1529. All the NERICA tested were early maturing compared to the local variety. Earliness is a selection criterion of the varieties especially for a country like Niger where the second rice cultivation season is subdivided into two. Hence, the principal constraints are the overlapping of the rainfed and irrigated farming calendars (AW et al., 1998). The growing cycle of interspecific is on average 140 days after sowings (DAS) and sometimes less than 140 DAS with variety NERICA-L16 (139 DAS). Score 1 of phenotypic acceptability is a good indicator of adaptation of the NERICA to the agro ecosystem of the three sites in particular and Niger in general. 
The yield of the NERICA tested was significantly increased because of the rainy season conditions. NERICA-L-49 recorded up to 7.4 ton/ha (Table 5). For rice producer in Niger the opportunity arises to lay out a range of variety of dry season and another of rainy season.

The use of the varieties NERICA-L-49, NERICA-L-39 and WAS 4-B-B-9-1-4TGR48 in the farming systems that includes rice in Niger (SNDI/CER, 2003) causes profits of production of 3.4, 3.2, and 3 tons / ha respectively, compared to the national average yield which is of 4 ton/ha (AW et al., 1998).

The study emphasized an average yield recorded for each NERICA variety tested. NERICA-L-49 was highest with 7.25 ton/ha followed NERICA-L-39 with 6.71 ton/ha and WAS 4-B-B-9-1-4-TGR 48 with 6.7 tons/ ha (Table 7).

\section{Socio-economic studies}

The agricultural research made enormous efforts in Africa but unfortunately, these remain unimportant because of the low level of adoption and inadequate technologies transfer (Sido, 2006). This is explained by the fact that the tests are carried out in places completely different from the real medium (the needs and perceptions of the producers were by no means taken into account in breeding and selection criteria). The methodological step of intervention under field condition INRAN differs from these old methods. This includes proposing the technology transfer unit improved varieties which answers only the concerns of the agronomist which is primarily good yield.

Also, the concern of meeting the needs for the producers requires taking into account their perceptions from the beginning of the breeding in order to ensure a better profitability of the investments. Indeed, the involvement of the farmers, at the beginning of the process makes it possible to lead to varieties that they already appreciate. This ensures a high rate of adoption and avoids making inefficient investments (Sido et al., 2006). It is in this spirit that INRAN, in collaboration with the PAFRIZ, started this activity of evaluation and extension of improved varieties of rice on some irrigation schemes. The six varieties tested in dry cropping season were not always the best in terms of yield. This is why, beyond the agronomic evaluation of the tests, we took into account perceptions of the producers to ensure the choice of varieties which meet their needs.

Field visits were organized at the maturity stage. During these visits, the producers had the opportunity of observing the trials and of giving their appreciations. This also enables them to answer later questions on the basis of questionnaires structured to enable us identify their selection criteria. The point of view of rice processors and producers which are at the same time consumers are essential in the choice of the varieties. This evaluation enabled us to know the selection criteria of the farmers so that the breeders take them into account in their selection criteria, provide the producers, the genetic material which they have chosen, thus ensuring a high rate of adoption and a strong profitability of the investments in research.

\section{Participative evaluation in dry season 2006}

During the dry season 2006, INRAN organized a field visit for about 20 farmers by site who tested and classified the 6 varieties as shown in Table 8.

The results from Table 8 clearly show that for the producers, the criteria that determines their choices go beyond the yield, NERICA-L-49 occupies the third rank $(7,1$ $\mathrm{T} / \mathrm{ha}$ ) whereas it was more productive than classified NERICA-L-39 ranked first with 6,1 $\mathrm{T} / \mathrm{ha}$. For better understanding of their choice, a field visit on larger scale was organized with the financial support of the PAFRIZ to allow us in a more formal way to address a much more representative sample. 


\section{Participative evaluation in rainy season 2006}

The conclusion on the choice from the producers follows all the stages of the farmers' evaluation to fix oneself on their choice taking account of all the parameters into account. The results of participation are shown in Table 9.

Eleven producers gave their point of view on the variety NERICA-L-49, $45 \%$ classified in first place because of good qualities of the heads and tillering which indicates a good production. It also presents shielding panicular leaves.

\section{Results from the milling and taste evaluation \\ Rice milling}

Rice pre-conditioning

Data in Table 10 show the initial moisture content varying from 8.43 to 13.76 $\%$ for the white rice samples, and from 10.47 to 13.20 for the parboiled rice.

For good milling, white rice grain moisture content should be in the range between 12 to $16 \%$. Therefore, all the samples were preconditioned at moisture content between 13 to $15 \%$.

Rice husking and whitening

The results from the evaluation of the samples for milling quality, in terms of time of husking, milling yield, percentages of bran and husk are reported in Table 11. For non parboiled rice, the values of these parameters vary respectively from 3 minutes 40 seconds (IR1529) to 5 minutes 16 seconds (NERICAL-39); 61\% (WAS 173-B-B-13-7-TGR21) to $68 \%$ (WAS 4-B-B-9-1-4-TGR 48); $11 \%$ (NERICA-L-49) to $17 \%$ (WAS 173-B-B-137-TGR21), and 20\% (IR 1529 and NERICAL-16) to $22 \%$ (WAS 114-B-IDSA-B-WAS-11-TGR 144, WAS 173-B-B-13-7-TGR21 and NERICA-L-49).

For parboiled rice, the time of husking fluctuates between 4 minutes 40 seconds (IR1529) and 6 minutes 30 seconds (WAS 173-B-B-13-7-TGR21 and NERICA-L-39) while the milling yield, bran and husk are respectively around $73,6 \%$ and $21 \%$. It is advisable to specify that the milling yield which constitutes the most important parameter of the data of Table 11 indicates here the sum of the white rice and cargo rice (that certain professionals call milling yield). The results of the analysis as of these fractions of husked grains (Table 12), showed that the percentages of white rice and cargo rice (compared to paddy) of the non parboiled samples varied respectively from 53\% (WAS 173-B-B-13-7-TGR21) to 59\% (WAS 4-B-B9-1-4-TGR 48 and NERICA-L-16) and 8\% (NERICA-L-16, WAS 173-B-B-13-7-TGR21, and IR1529) with $12 \%$ (NERICA-L-49). For parboiled samples, the values of these parameters oscillate between $63 \%$ (WAS 173B-B-13-7-TGR21) and 68\% (WAS 4-B-B-91-4-TGR 48 and NERICA-L-16) and 6\% (NERICA-L-49 and WAS 4-B-B-9-1-4-TGR 48) and 10\% (WAS 173-B-B-13-7-TGR21).

Following the example of price and whiteness of rice, the percentage of broken rice also constitutes another determinant of the commercial value of rice. For that, we evaluated the percentage of broken rice of the milled rice obtained from each sample. The results obtained are given in Table 13. These results showed high percentage of broken rice which varied from $31 \% 9$ (WAS 114-BIDSA-B-WAS-1-1-TGR 144) to $57 \%$ (WAS 4-B-B-9-1-4-TGR 48) for non parboiled rice. It was relatively low for the parboiled rice. It fluctuated between $3.5 \%$ (WAS 173-B-B-137-TGR21) and 12\% (WAS 4-B-B-9-1-4-TGR 48).

From the results shown in Tables 11, 12 and 13, the following were the principals' tendencies:

- Whatever the variety of rice considered, the milling yield and white rice of the parboiled samples were higher than those of the non parboiled samples. On the contrary, the percentage broken rice of the parboiled samples was significantly lower than that of non parboiled rice. This was in agreement 
with the opinions of people involved in rice production in general and processors in particular. On the other hand, all factors considered, the Cargo rice yield of the non parboiled rice samples seems to be comparable with that of the parboiled samples with the idea according to which the percentage of Cargo rice would be in relation to the capacity and the efficiency of the husking machine from where its designation of milling yield by certain professionals in rice milling;

- The amplitude of the variation of the milling yield, in white rice and the percentage broken from the whitened rice was higher in non parboiled rice than in the parboiled samples. It was about 7 points for the milling yield, 6 points for white rice yield and 26 points for the percentage broken grain with regard to the non-parboiled samples against respectively 1,5 , and 9 points for the parboiled samples. These results showed that the rate of broken grain of the milled rice indeed constitutes a powerful factor of discrimination of milling quality of rice varieties. For the cargo rice yield, this amplitude seems to be constantly around 4 points.

\section{Rice tasting (degustation)}

The results of the sensory evaluation of the milling of non parboiled and parboiled samples are respectively given in Tables 14 and 15 .

Compared to the non parboiled samples, the results in Table 14 show that the score (and the ranking) of each variety of rice varied according to the organoleptic parameter considered. On the basis of classification, according to general acceptability integrating the color, the stickiness and the taste, variety NERICA-L-39 parboiled with a score of 25 was the most preferred by consumers. It was followed by NERICA-L-16 and WAS 173-BB-13-7-TGR21 with respective scores of 21 and 17 points.

For the parboiled rice samples as shown in Table 15, consumers preferred the varieties NERICA-L-49, NERICA-L-39 and WAS 4-B-B-9-1-4-TGR 48 with scores 23, 22 , and 18 points respectively.

From the analysis of data (Tables 14 and 15), it was clear that on the organoleptic level, all introduced NERICA varieties outclassed the local check (IR1529). Variety NERICA-L-39 scored high both when parboiled and not parboiled. Indeed, it occupied $2^{\text {nd }}$ or 1 st place depending on whether it was parboiled or not. On the basis of the scores obtained, according to the rice milling technique, the NERICA-L- 49 variety (23 points when parboiled) had an interesting potential.

Table 2: Average yield (t / ha) Dry season 2006.

\begin{tabular}{lccc}
\hline Variety & $\begin{array}{c}\text { Yield } \\
\text { (T/ha) }\end{array}$ & IR1529\% & Gain production / local \\
\hline WAS 4-B-B-9-1-4-TGR 48 & $6,48 \mathrm{~b}$ & 105 & 0,34 \\
NERICA-L-16 & $5,8 \mathrm{~d}$ & 94 & $-0,34$ \\
WAS 114-B-IDSA-B-WAS-1-1-TGR 144 & $5,7 \mathrm{~d}$ & 92 & $-0,44$ \\
WAS 173-B-B-13-7-TGR21 & $6,19 \mathrm{c}$ & 101 & 0,05 \\
NERICA-L-39 & $6,19 \mathrm{c}$ & 101 & 0,05 \\
NERICA-L-49 & $7,13 \mathrm{a}$ & 116 & 0,99 \\
IR1529 (local check) & $6,14 \mathrm{c}$ & 100 & \\
\hline
\end{tabular}


Table 3: Average yield ( $\mathrm{t} / \mathrm{ha}$ ) by site dry season 2006.

\begin{tabular}{lcccc}
\hline Variety & \multicolumn{3}{c}{ Sites } & \multirow{2}{*}{ Mean } \\
\cline { 2 - 4 } & Diambala & Karma & Sébéry & \\
\hline WAS 4-B-B-9-1-4-TGR 48 & 6,43 & 6,41 & 6,44 & 6,4 \\
NERICA-L-16 & 5,8 & 5,9 & 5,76 & 5,8 \\
WAS 114-B-IDSA-B-WAS-1-1-TGR 144 & 5,73 & 5,73 & 5,7 & 5,7 \\
WAS 173-B-B-13-7-TGR21 & 6,13 & 6,1 & 6,09 & 6,1 \\
NERICA-L-39 & 6,13 & 6,13 & 6,05 & 6,1 \\
NERICA-L-49 & 7,1 & 7,17 & 7,07 & 7,1 \\
IR1529 ( local check) & 6,1 & 6,19 & 6,1 & 6,1 \\
\hline
\end{tabular}

Table 4: Agronomic characteristics of the tested varieties in 2006 (dry season).

\begin{tabular}{lcccccc}
\hline Variety & $\begin{array}{c}\text { Height } \\
(\mathbf{c m})\end{array}$ & $\begin{array}{c}\text { Cycle } \\
(\mathbf{d a y s})\end{array}$ & $\begin{array}{c}\text { Panicle } \\
\left(\mathbf{m}^{2}\right)\end{array}$ & $\begin{array}{c}\text { Sterility } \\
(\mathbf{\%})\end{array}$ & $\begin{array}{c}\text { 1000 grain } \\
\text { weight } \\
(\mathbf{g})\end{array}$ & $\begin{array}{c}\text { Phenotypic } \\
\text { acceptability }\end{array}$ \\
\hline WAS 4-B-B-9-1-4-TGR 48 & $121,7 \mathrm{dc}$ & $142,1 \mathrm{~b}$ & $113 \mathrm{a}$ & $17,1 \mathrm{~cd}$ & $22,8 \mathrm{bc}$ & 1 \\
NERICA-L-16 & $128,06 \mathrm{a}$ & $139,5 \mathrm{c}$ & $319,6 \mathrm{a}$ & $16,3 \mathrm{~d}$ & $22,8 \mathrm{bc}$ & 1 \\
WAS 114-B-IDSA-B- & $119,4 \mathrm{~d}$ & $141 \mathrm{bc}$ & $337,9 \mathrm{a}$ & $16,01 \mathrm{~d}$ & $23,54 \mathrm{ab}$ & 1 \\
WAS-1-1-TGR 144 & & & & & & \\
WAS 173-B-B-13-7-TGR21 & $119,9 \mathrm{~d}$ & $142,1 \mathrm{~b}$ & $326,07 \mathrm{a}$ & $16 \mathrm{~d}$ & $22,9 \mathrm{bc}$ & 1 \\
NERICA-L-39 & $121,8 \mathrm{c}$ & $141,3 \mathrm{~b}$ & $333,8 \mathrm{a}$ & $18,5 \mathrm{c}$ & $22,6 \mathrm{bc}$ & 1 \\
NERICA-L-49 & $124,4 \mathrm{~b}$ & $141,5 \mathrm{~b}$ & $329 \mathrm{a}$ & $21,1 \mathrm{~b}$ & $22,8 \mathrm{a}$ & 1 \\
IR1529 (local check) & $127,6 \mathrm{a}$ & $150 \mathrm{a}$ & $317 \mathrm{a}$ & $24,4 \mathrm{a}$ & $23,18 \mathrm{a}$ & 1 \\
\hline \multicolumn{2}{l}{ Means followed with the same letter are not significantly different (DMRT 50\%). } & &
\end{tabular}

Means followed with the same letter are not significantly different (DMRT 50\%).

Table 5: Mean yield (ton/ha) per site in 2006 (rainy season).

\begin{tabular}{lcccc}
\hline Variety & \multicolumn{3}{c}{ Sites } & \multirow{2}{*}{ Mean } \\
\cline { 2 - 4 } & Diambala & Karma & Sébéry & \\
\hline WAS 4-B-B-9-1-4-TGR 48 & 6,8 & 6,9 & 7,3 & 7,0 \\
NERICA-L-16 & 6,4 & 5,9 & 6,8 & 6,3 \\
WAS 114-B-IDSA-B-WAS-1-1-TGR 144 & 6,1 & 5,9 & 6,0 & 6,0 \\
WAS 173-B-B-13-7-TGR21 & 6,3 & 6,1 & 5,9 & 6,1 \\
NERICA-L-39 & 7,2 & 7,1 & 7,5 & 7,2 \\
NERICA-L-49 & 7,8 & 7,1 & 7,4 & 7,4 \\
IR1529 ( local check) & 6,6 & 5,9 & 6,5 & 6,3 \\
\hline
\end{tabular}


Table 6: Productivity gain over the national average yield.

\begin{tabular}{lcc}
\hline Variety & $\begin{array}{c}\text { Mean yield } \\
(\mathbf{T} / \mathbf{h a})\end{array}$ & $\begin{array}{c}\text { Productivity gain over } \\
\text { national average yield (T/ha) }\end{array}$ \\
\hline WAS 4-B-B-9-1-4-TGR 48 & 7,0 & 3 \\
NERICA-L-16 & 6,3 & 2,3 \\
WAS 114-B-IDSA-B-WAS-1-1-TGR 144 & 6,0 & 2 \\
WAS 173-B-B-13-7-TGR21 & 6,1 & 2,1 \\
NERICA-L-39 & 7,2 & 3,2 \\
NERICA-L-49 & 7,4 & 3,4 \\
IR1529 ( local check) & 6,3 & 2,3 \\
\hline
\end{tabular}

Table 7: Dry and rainy seasons mean yield in 2006.

\begin{tabular}{lccc}
\hline \multirow{2}{*}{ Variety } & \multicolumn{3}{c}{ Yield (T/ha) } \\
\cline { 2 - 4 } & Dry season & Rainy season & Average \\
\hline WAS 4-B-B-9-1-4-TGR 48 & 6,4 & 7,0 & 6,7 \\
NERICA-L-16 & 5,8 & 6,3 & 6,05 \\
WAS 114-B-IDSA-B-WAS-1-1-TGR 144 & 5,7 & 6,0 & 5,85 \\
WAS 173-B-B-13-7-TGR21 & 6,1 & 6,1 & 6,1 \\
NERICA-L-39 & 6,1 & 7,3 & 6,7 \\
NERICA-L-49 & 7,1 & 7,4 & 7,25 \\
IR1529 ( local check) & 6,1 & 6,3 & 6,2 \\
\hline
\end{tabular}

Table 8: Farmers' appreciations.

\begin{tabular}{lcc}
\hline Variety & Average yield (T/ ha) & Ranking \\
\hline NERICA-L-39 & 6,1 & 1 \\
WAS 173-B-B-13-7-TGR21 & 6,1 & 2 \\
NERICA-L-49 & 7,1 & 3 \\
WAS 4-B-B-9-1-4-TGR 48 & 6,4 & 4 \\
NERICA-L-16 & 5,8 & 5 \\
WAS 114-B-IDSA-B-WAS-1-1-TGR 144 & 5,7 & 6 \\
\hline
\end{tabular}

Table 9: Farmers' appreciations of NERICA-L-49.

\begin{tabular}{llll}
\hline Variety & Number of farmers & Ranking & Raison \\
\hline NERICA-L-49 & 4 & 1 & $\begin{array}{l}\text { Good panicle, good yield, shielding-like } \\
\text { panicular leaf, large grain size }\end{array}$ \\
\cline { 2 - 4 } & 2 & 2 & Long panicle, good yield \\
\cline { 2 - 4 } & 2 & 3 & $\begin{array}{l}\text { Good panicle, good tillering, 240 grains } \\
\text { per panicle }\end{array}$ \\
\cline { 2 - 4 } & 1 & 5 & Appreciable port, good tillering \\
& 1 & 6 & Appreciable port, good tillering \\
& & 7 & Low yield \\
\hline
\end{tabular}


Table 10: Moisture content of paddy grain (white and parboiled rice).

\begin{tabular}{lcc}
\hline Variety & \multicolumn{2}{c}{ Paddy grain } \\
\cline { 2 - 3 } & White rice (\%) & Parboiled rice (\%) \\
\hline WAS 4-B-B-9-1-4-TGR 48 & 10,30 & 11,06 \\
NERICA-L-16 & 13,76 & 11,10 \\
WAS 114-B-IDSA-B-WAS-1-1-TGR 144 & 8,69 & 13,20 \\
WAS 173-B-B-13-7-TGR21 & 11,25 & 11,42 \\
NERICA-L-39 & 8,43 & 12,50 \\
NERICA-L-49 & 9,21 & 11,27 \\
IR1529 & 12,22 & 10,47 \\
\hline
\end{tabular}

Table 11: Overall settings decorticating.

\begin{tabular}{lcccccccc}
\hline Variety & \multicolumn{3}{c}{ Non parboiled rice } & \multicolumn{3}{c}{ Parboiled rice } \\
\hline & $\begin{array}{c}\text { Time } \\
(\mathbf{m n})\end{array}$ & $\begin{array}{c}\text { Milled } \\
\text { rice } \\
(\boldsymbol{\%})\end{array}$ & $\begin{array}{c}\text { Bran } \\
(\boldsymbol{\%})\end{array}$ & $\begin{array}{c}\text { Husk } \\
(\boldsymbol{\%})\end{array}$ & $\begin{array}{c}\text { Time } \\
(\mathbf{m n})\end{array}$ & $\begin{array}{c}\text { Milled } \\
\text { rice } \\
(\boldsymbol{\%})\end{array}$ & $\begin{array}{c}\text { Bran } \\
(\boldsymbol{\%})\end{array}$ & $\begin{array}{c}\text { Husk } \\
(\boldsymbol{\%})\end{array}$ \\
\hline $\begin{array}{l}\text { WAS 4-B-B-9-1-4-TGR } \\
\text { 48 }\end{array}$ & 4.16 & 67.71 & 11.68 & 20.60 & 4.55 & 73.84 & 5.85 & 20.30 \\
\hline NERICA-L-16 & & & & & & & & \\
\hline $\begin{array}{l}\text { WAS 114-B-IDSA-B- } \\
\text { WAS-1-1-TGR 144 }\end{array}$ & 4.42 & 66.83 & 13.37 & 19.80 & 5.10 & 73.39 & 5.78 & 20.83 \\
\hline $\begin{array}{l}\text { WAS 173-B-B-13-7- } \\
\text { TGR21 }\end{array}$ & 4.46 & 65.13 & 13.04 & 21.83 & 5.06 & 72.91 & 6.21 & 20.83 \\
\hline NERICA-L-39 & & & & & & & & \\
\hline NERICA-L-49 & 5.16 & 66.86 & 12.39 & 20.75 & 6.29 & 72.81 & 6.13 & 21.06 \\
\hline IR1529 & 4.22 & 66.03 & 11.48 & 22.49 & 5.47 & 72.94 & 5.58 & 21.48 \\
\hline
\end{tabular}

Table 12: Distribution of grain husked rice and milled rice.

\begin{tabular}{lcccccc}
\hline Variety & \multicolumn{5}{c}{ Fractions } \\
\cline { 2 - 7 } & $\begin{array}{c}\text { Milled } \\
\text { rice } \\
\text { yield }\end{array}$ & $\begin{array}{c}\text { White } \\
\text { rice }(\%)\end{array}$ & $\begin{array}{c}\text { Cargo } \\
(\%)\end{array}$ & $\begin{array}{c}\text { Milled } \\
\text { rice yield }\end{array}$ & $\begin{array}{c}\text { White } \\
\text { rice (\%) }\end{array}$ & Cargo (\%) \\
& & & & & 6.03 \\
\hline WAS 4-B-B-9-1-4-TGR 48 & 67.71 & 59.02 & 8.69 & 73.84 & 67.81 & 5.70 \\
NERICA-L-16 & 66.82 & 59.25 & 7.59 & 73.39 & 67.69 & 8.99 \\
WAS 114-B-IDSA-B-WAS-1- & 65.13 & 54.37 & 10.75 & 72.91 & 63.92 & 9.80 \\
1-TGR 144 & & & & & & 6.83 \\
WAS 173-B-B-13-7-TGR21 & 61.13 & 53.42 & 7.71 & 73.07 & 63.27 & 6.16 \\
NERICA-L-39 & 66.86 & 57.41 & 9.45 & 72.81 & 65.98 & 8.34 \\
NERICA-L-49 & 66.03 & 53.94 & 12.09 & 72.94 & 66.78 & \\
IR1529 & 66.18 & 58.32 & 7.86 & 72.64 & 64.30 & \\
\hline
\end{tabular}


A. SIDO YACOUBA et al. / Int. J. Biol. Chem. Sci. 7(6): 2202-2213, 2013

Table 13: Results of fractions analysis for milled rice.

\begin{tabular}{|c|c|c|c|c|c|c|}
\hline \multirow[t]{3}{*}{ Variety } & \multicolumn{6}{|c|}{ Fractions (compared to $100 \mathrm{~g}$ white rice) } \\
\hline & \multicolumn{3}{|c|}{ Non parboiled rice } & \multicolumn{3}{|c|}{ Parboiled rice } \\
\hline & $\begin{array}{c}\text { Whole gain } \\
\%\end{array}$ & $\begin{array}{c}\text { Broken rice } \\
(\%)\end{array}$ & $\begin{array}{c}\text { impurities } \\
(\%)\end{array}$ & $\begin{array}{c}\text { Whole gain } \\
\%\end{array}$ & $\begin{array}{c}\text { Broken rice } \\
(\%)\end{array}$ & $\begin{array}{c}\text { impurities } \\
(\%)\end{array}$ \\
\hline WAS 4-B-B-9-1-4-TGR 48 & 42.29 & 57.17 & 1.54 & 87.69 & 11.64 & 0.67 \\
\hline NERICA-L-16 & 62.75 & 35.48 & 1.77 & 91.37 & 8.37 & 0.26 \\
\hline WAS 114-B-IDSA-B-WAS-1-1-TGR 144 & 68.38 & 31.24 & 0.38 & 87.13 & 12.39 & 0.48 \\
\hline WAS 173-B-B-13-7-TGR21 & 54.09 & 43.75 & 2.16 & 96.16 & 3.52 & 0.33 \\
\hline NERICA-L-39 & 53.74 & 45.78 & 0.48 & 94.51 & 5.15 & 0.34 \\
\hline NERICA-L-49 & 48.53 & 50.89 & 0.58 & 92.28 & 7.08 & 0.64 \\
\hline IR1529 & 41.82 & 56.41 & 1.76 & 92.93 & 6.81 & 0.26 \\
\hline
\end{tabular}

Table 14: Results from non-parboiled rice taste study.

\begin{tabular}{lcccccccc}
\hline Variety & \multicolumn{2}{c}{ Color } & \multicolumn{2}{c}{ Stickiness } & \multicolumn{2}{c}{ Taste } & \multicolumn{2}{c}{ Acceptability } \\
\cline { 2 - 9 } & Score & rank & Score & rank & Score & Rank & Score & Rank \\
\hline WAS 4-B-B-9-1-4-TGR 48 & 16 & 5 th & 15 & 4 th & 9 & $7^{\text {th }}$ & 10 & $6^{\text {th }}$ \\
NERICA-L-16 & 21 & 2 nd & 10 & 6 th & 20 & $2^{\text {nd }}$ & 21 & $2^{\text {nd }}$ \\
WAS 114-B-IDSA-B-WAS-1- & 7 & 7 th & 24 & $1 \mathrm{st}$ & 14 & $5^{\text {th }}$ & 16 & $4^{\text {th }}$ \\
1-TGR 144 & & & & & & & & \\
WAS 173-B-B-13-7-TGR21 & 9 & 6 th & 23 & 2 nd & 24 & $1^{\text {st }}$ & 17 & 3 trd \\
NERICA-L-39 & 18 & 4 th & 8 & 7 th & 17 & $3^{\text {rd }}$ & 25 & $1^{\text {st }}$ \\
NERICA-L-49 & 19 & 3 rd & 14 & 5 th & 15 & $4^{\text {th }}$ & 13 & $5^{\text {th }}$ \\
IR1529 & 22 & 1 st & 18 & 3 rd & 13 & $6^{\text {th }}$ & 9 & $7^{\text {th }}$ \\
\hline
\end{tabular}


Table 15: Results from the parboiled rice taste study.

\begin{tabular}{lcccccccc}
\hline \multirow{2}{*}{ Variety } & \multicolumn{2}{c}{ Color } & \multicolumn{2}{c}{ Stickiness } & \multicolumn{2}{c}{ Taste } & \multicolumn{2}{c}{ Acceptability } \\
\cline { 2 - 9 } & Score & rank & Score & rank & Score & Rank & Score & Rank \\
\hline WAS 4-B-B-9-1-4-TGR 48 & 20 & 3rd & 9 & 7 th & 20 & $2^{\text {nd }}$ & 18 & $3^{\text {rd }}$ \\
NERICA-L-16 & 13 & 5 th & 10 & 6 th & 16 & $3^{\text {rd }}$ & 11 & $6^{\text {th }}$ \\
WAS 114-B-IDSA-B-WAS-1-1- & 24 & 1 st & 11 & 5 th & 16 & 3 trd & 17 & $4^{\text {th }}$ \\
TGR 144 & & & & & & & & \\
WAS 173-B-B-13-7-TGR21 & 12 & 6 th & 22 & 2 nd & 11 & $7^{\text {th }}$ & 13 & $5^{\text {th }}$ \\
NERICA-L-39 & 14 & 4 th & 18 & 3 rd & 21 & $1^{\text {st }}$ & 22 & $2^{\text {nd }}$ \\
NERICA-L-49 & 22 & 2nd & 16 & 4 th & 15 & $5^{\text {th }}$ & 23 & $1^{\text {st }}$ \\
IR1529 & 7 & 7 th & 26 & 1 st & 13 & $6^{\text {th }}$ & 8 & $7^{\text {th }}$ \\
\hline
\end{tabular}

\section{Conclusion}

This study on introduction and evaluation of irrigated NERICA in Niger (during two rice growing seasons dry season and rainy season), in 2006, made it possible to draw the following conclusions:

1. On agronomic level, three varieties were put forward and were selected for their high yielding potential of approximately 7 tons per ha. These were: NERICA-L-49, NERICA-L39 and WAS 4-B-B-9-1-4-TGR 48.

2. On socio economic aspects, the variety NERICA-L-49 was appreciated by the farmers.

3. On the technological and organoleptic level: taking into consideration results from the rice taste evaluation, it was very difficult to give a clear tendency. Broadly, the varieties that were tested presented comparable milling output and white rice yields. However varieties WAS 4-B-B-9-1-4TGR 48 and NERICA-L-16 recorded the best milling results in rice output and in white rice. On the other hand, in terms of organoleptic levels, all the introduced varieties of NERICA scored higher than the local check (IR1529). The best varieties were NERICA L-39 and NERICA L-49. Considering their interesting results in milling yield when parboiled, it will be desirable that the screening work continues on these varieties.

Finally, the comprehensive assessment (agronomic, socio economic, technological and organoleptic quality) made it possible to retain two varieties NERICA: NERICA-L49, NERICA-L-39, and one intraspecific,
WAS 4-B-B-9-1-4-TGR 48. These three varieties were approved in 2007. These new varieties were registered in national catalogue of plant species and varieties in 2012 . Currently, these varieties are disseminated on all irrigation schemes of Niger.

\section{REFERENCES}

ADRAO. 2005. Rapport annuel 2003-2004: vers de nouveaux horizons. Cotonou, Benin, 56p.

ADRAO. 1996. Rapport annuel, 112p. Catalogue National des Espèces et Variétés végétales (CNEV). 279p.

CIRAD. 2000. Etude de faisabilité du programme d'appui à la filière riz (PAFRIZ).

Aw D, Sousou M, Sido Y. 1998. Analyse de la filière riz au Niger. CT/FAO, Niamey, Niger, 58p.

Hamadou S, Sido AY. 1998. Sélection variétale participative de riz au Niger. Rapport PRIGA. Niamey, INRANADRAO, 38p.

ONAHA.1999. Rapport d'activités, 32p.

ROCARIZ. 2005. Rapport d'activités, 78p.

Sido YA. 2006. Rapport INRAN/PAFRIZ, $56 \mathrm{p}$.

SNDI/CER. 2003. Stratégie National de Développement de l'Irrigation et Collecte des Eaux de Ruissellement, SNDI/CER, 175p.

Sido YA, Basso A, Halidou A, Ibro G. 2006. Evaluation des lignées intra et interspécifiques de riz de bas fond/irrigué, Proceedings of Africa Rice Congress, p.9-12. 